\title{
Does Parathyroid Hormone Affect Erythropoietin Therapy in Dialysis Patients?
}

\author{
Nabieh Al-Hilali ${ }^{a}$ Hani Al-Humoud ${ }^{a}$ b Vadakethu T. Ninan ${ }^{a}$ \\ Mangalathillam R.N. Nampoory ${ }^{a}$ Mini A. Puliyclil ${ }^{b}$ Kaivilayil V. Johny ${ }^{a}$ b \\ ${ }^{a}$ Department of Medicine, Mubarak Al-Kabeer Hospital and ${ }^{b}$ Faculty of Medicine Kuwait University, Kuwait
}

\section{Key Words}

Hyperparathyroidism - Anemia - Hemodialysis •

Peritoneal dialysis $\cdot$ Recombinant human erythropoietin

\begin{abstract}
Objective: The objective of this study was to assess the response to recombinant human erythropoietin (rHuEPO) during treatment of anemia in dialysis patients with hyperparathyroidism. Subjects and Methods: A total of 118 patients with stage 5 renal failure on dialysis therapy were selected for this study. Anemia was treated with rHuEPO. Laboratory data for each patient included intact parathyroid hormone (iPTH), hemoglobin $(\mathrm{Hb})$, hematocrit $(\mathrm{Hct})$, blood urea nitrogen, serum creatinine, calcium, phosphate, and alkaline phosphatase. Patients with iPTH $>32 \mathrm{pmol} / \mathrm{l}$ were considered hyperparathyroid. Erythropoietin resistance index (ERI) was expressed as the ratio of weekly rHuEPO dose/Hct level. Results: Of the 118 patients, 83 (70.3\%) were on hemodialysis (HD) and 35 (29.7\%) were on continuous ambulatory peritoneal dialysis (CAPD). Sixty-three patients (64.3\%) with iPTH $>32 \mathrm{pmol} / / \mathrm{l}$ had $\mathrm{Hb}<11 \mathrm{~g} / \mathrm{dl}$, while 34 (54.8\%) with iPTH $<32$ had Hb $>11 \mathrm{~g} / \mathrm{dl}(\mathrm{p}=04)$. Thirty-three (56\%) patients with $\mathrm{PTTH}>32 \mathrm{pmol} / \mathrm{l}$ had hemocrit $<33 \%$, while $38(61.3 \%)$ with iPTH $<32$ had hemocrit $<33 \%(p=0.4)$. The median value of weekly rHuEPO dose in HD patients (12,000 units) was significantly higher in comparison with CAPD patients $(6,000$
\end{abstract}

(C) 2007 S. Karger AG, Basel

$1011-7571 / 07 / 0161-0063 \$ 23.50 / 0$

ax +41613061234

E-Mail karger@karger.ch

www.karger.com
Accessible online at:

www.karger.com/mpp units; $p<0.0001)$. ERI was significantly higher in HD than CAPD patients with iPTH $<16 \mathrm{pmol} / \mathrm{l}(\mathrm{p}=0002)$ as well as with patients with $16-32 \mathrm{pmol} / \mathrm{l}(p=0.012)$. Conclusions: CAPD patients showed a reduced requirement for rHuEPO and better control of anemia compared with HD patients. ERI was also lower in CAPD than in HD patients. Hyperparathyroidism is a parameter predictive of rHuEPO hyporesponsiveness in dialysis patients.

Copyright $\odot 2007$ S. Karger AG, Basel

\section{Introduction}

Anemia is a common concomitant disorder in dialysis patients. Improving the quality of life in these patients has been achieved by the use of recombinant human erythropoietin (rHuEPO), which became routine in the 1980s [1]. However, factors contributing to the degree of refractory anemia or so-called 'erythropoietin hyporesponsiveness' in dialysis patients are not well understood. Functional iron deficiency, blood loss, secondary hyperparathyroidism, aluminum toxicity, interaction with other drugs, infection and inflammatory conditions have been considered as predictors of poor response to erythropoietin treatment of anemia [2-5]. Secondary hyperparathyroidism is known to induce bone marrow fibrosis, impaired erythropoiesis [6] and inhibition of endog-

Dr. Hani Al-Humoud

Department of Medicine, Mubarak Al-Kabeer Hospital PO Box 24923

Safat 13110 (Kuwait)

Tel. +965 715 582, Fax +965 5330 002, E-Mail hanialhumoud@yahoo.com 
Table 1. Demographic features of studied patients

\begin{tabular}{lccc}
\hline Patients & HD & CAPD & p value \\
\hline $\begin{array}{l}\text { Number } \\
\text { Age, years }\end{array} \quad 83$ & 35 & \\
$\quad$ Range & & & \\
$\quad$ Mean \pm SD & $51.5 \pm 15.2$ & $55.8 \pm 13.3$ & \\
Gender & & & \\
$\quad$ Male & $30(36.1 \%)$ & $20(57.1 \%)$ & $0.023^{\mathrm{a}}$ \\
$\quad$ Female & $53(63.9 \%)$ & $15(42.9 \%)$ & \\
Time on dialysis, months & & & \\
$\quad$ Range & $4.0-217.0$ & $4.0-91.8$ & $0.004^{\mathrm{a}}$ \\
$\quad$ Mean \pm SD & $32.1 \pm 2.4$ & $19.2 \pm 2.1$ & \\
Renal disease & & & \\
$\quad$ Diabetic & $20(24.1 \%)$ & $11(31.4 \%)$ & $0.779^{\mathrm{b}}$ \\
Chronic GN & $20(24.1 \%)$ & $11(31.4 \%)$ & \\
$\quad$ Chronic IN & $16(19.3 \%)$ & $5(14.3 \%)$ & \\
$\quad$ Hypertension & $10(12 \%)$ & $3(8.6 \%)$ & \\
$\quad$ Others & $4(4.8 \%)$ & $1(2.9 \%)$ & \\
\hline
\end{tabular}

HD = Hemodialysis CAPD = continuous ambulatory peritoneal dialysis; $\mathrm{GN}=$ glomerulonephritis; $\mathrm{IN}=$ interstitial nephritis.

${ }^{a}$ Nonparametric Mann-Whitney test.

${ }^{\mathrm{b}} \chi^{2}$ test.

enous production of erythropoietin [7]. The impact of intact parathyroid hormone (iPTH) on the responsiveness to $\mathrm{rHuEPO}$ in dialysis patients is still not well understood. The purpose of this study was to assess the response to $\mathrm{rHuEPO}$ during treatment of anemia in dialysis patients with hyperparathyroidism.

\section{Subjects and Methods}

Patients who had been on renal replacement therapy for at least 6 months were selected for this study. All patients on hemodialysis (HD) were receiving three sessions a week utilizing hollow fiber dialyzers (regenerated cellulose or polysulfone). Patients on continuous ambulatory peritoneal dialysis (CAPD) were using the double bag system. All patients were on a stable rHuEPO dose, hemoglobin $(\mathrm{Hb})$ level and medications for at least 3 months before the study. Medications included intravenous rHuEPO (epoetin beta), alfacalcidol capsules $0.25-0.5 \mu \mathrm{g}$ /day orally or in pulse therapy 2-8 $\mu \mathrm{g} /$ week, phosphate binders, antihypertensive drugs and vitamins. Patients with $\mathrm{Hb}$ concentration $<11 \mathrm{~g} / \mathrm{dl}$ and hematocrit $(\mathrm{Hct})<33 \%$ were considered anemic as recommended by Kidney-Dialysis Outcomes Quality Initiative: K/DOQI Clinical Practice Guidelines [8].

Laboratory data for each patient included $\mathrm{Hb}, \mathrm{Hct}$, blood urea nitrogen, serum creatinine, serum calcium corrected for the level of serum albumin, serum phosphorus and alkaline phosphatase
(AlP). All data were expressed as the mean value of 3 readings. Patients with iPTH $32 \mathrm{pmol} / \mathrm{l}$ or more were considered to have hyperparathyroidism as recommended by K/DOQI Clinical Practice Guidelines [9]. Erythropoietin resistance index (ERI) was expressed as the ratio of weekly $\mathrm{rHuEPO}$ dose/Hct level. The statistical package for social sciences was used for data processing using cut-off level for significance as $\mathrm{p} \leq 0.05$. Various descriptive statistics were used to define the median of variables. Nonparametric Mann-Whitney test was used to compare the medians of undependable variables. $\chi^{2}$ test and Fisher's exact test were used to define the association between independent variables, as appropriate. Spearman rank correlation was used to define the $\mathrm{p}$ value and correlation coefficient of independent variables.

\section{Results}

The demographic characteristics of the patients are given in table 1 . There was no significant difference in age between HD and peritoneal dialysis patients. The time on dialysis was significantly longer for HD (4-217 months) than CAPD $(4-91.8$ months) patients $(p=0.004)$. Diabetic nephropathy and chronic glomerulonephritis were the common causes of stage 5 renal disease in all studied patients.

Laboratory parameters of the patients are given in table 2. Intact iPTH was higher in HD (33 pmol/l) than in peritoneal dialysis $(24 \mathrm{pmol} / \mathrm{l})$ patients. The difference, however, was not significant ( $p=0.17$ ). Also, Hb, Hct, ferritin, calcium, phosophate and AlP levels were not significantly different between HD and CAPD patients ( $\mathrm{p}>$ $0.05)$. However, erythropoietin dose per week was significantly lower in CAPD than in HD $(\mathrm{p}<0.0001)$. ERI in peritoneal dialysis was significantly lower than in HD patients $(\mathrm{p}<0.004)$.

The relationship between $\mathrm{rHuEPO}$ resistance index and $\mathrm{iPTH}$ levels in HD and CAPD is shown in figure 1. rHuEPO resistance index was significantly higher in $\mathrm{HD}$ than CAPD patients with iPTH $<16 \mathrm{pmol} / \mathrm{l}(\mathrm{p}=0.002)$ as well as patients with $16-32 \mathrm{pmol} / \mathrm{l}(\mathrm{p}=0.012)$. There was no significant difference between HD and CAPD patients with iPTH higher than $32 \mathrm{pmol} / \mathrm{l}$.

$\mathrm{Hb}$ and Hct levels at iPTH level $<$ and $>32 \mathrm{pmol} / \mathrm{l}$ for all the patients are shown in table 3 . With $\mathrm{Hb}$ level $<11$ $\mathrm{g} / \mathrm{dl}$, more patients (36) had iPTH level $>32$ than when the level was $<11 \mathrm{~g} / \mathrm{dl}$ (28 patients); the difference was statistically significant $(\mathrm{p}=0.04)$. Also, with Hct level $<33 \%$ more patients (33) had iPTH level $>32$ than when the level was $>33 \%$; the difference was also statistically significant $(\mathrm{p}=0.044)$. 
Table 2. Laboratory parameters

\begin{tabular}{|c|c|c|c|c|c|c|c|}
\hline & \multicolumn{3}{|l|}{$\mathrm{HD}$} & \multicolumn{3}{|l|}{ CAPD } & \multirow[t]{2}{*}{$\mathrm{p}$ value $^{\mathrm{a}}$} \\
\hline & median & $\begin{array}{l}25 \text { th } \\
\text { percentile }\end{array}$ & $\begin{array}{l}\text { 75th } \\
\text { percentile }\end{array}$ & median & $\begin{array}{l}25 \text { th } \\
\text { percentile }\end{array}$ & $\begin{array}{l}\text { 75th } \\
\text { percentile }\end{array}$ & \\
\hline iPTH, pmol/l & 33 & 17.9 & 64.0 & 24 & 8.5 & 53.4 & 0.168 \\
\hline $\mathrm{Hb}, \mathrm{g} / \mathrm{dl}$ & 11 & 10.30 & 11.8 & 11 & 10.1 & 12.0 & 0.777 \\
\hline Hct, \% & 32 & 30.0 & 35.2 & 32 & 29.9 & 35.0 & 0.637 \\
\hline Ferritin, ng/ml & 130 & 71 & 236 & 194 & 123 & 279 & 0.035 \\
\hline rHuEPO dose, units/week & 12,000 & 6,000 & 1,200 & 6,000 & 4,000 & 8,000 & $<0.0001$ \\
\hline ERI & 317.46 & 193.54 & 467.28 & 192.9 & 125.0 & 280.7 & 0.001 \\
\hline Corrected $\mathrm{Ca}, \mathrm{mmol} / \mathrm{l}$ & 2.46 & 2.32 & 2.56 & 2.58 & 2.53 & 2.74 & 0.461 \\
\hline Phosphate, mmol/l & 1.81 & 1.42 & 2.2 & 1.52 & 1.20 & 2.04 & 0.089 \\
\hline Albumin, $g / 1$ & 32 & 30 & 34 & 28 & 23 & 33 & $<0.0001$ \\
\hline AlP, IU/l & 78.0 & 66.0 & 106.0 & 85.0 & 125 & 280 & 0.337 \\
\hline
\end{tabular}

$\mathrm{iPTH}=$ Intact parathyroid hormone; $\mathrm{rHuEPO}=$ recombinant human erythropoietin; AlP = alkaline phosphatase; ERI = recombinant human erythropoietin resistance index.

${ }^{a}$ Nonparametric Mann-Whitney test.

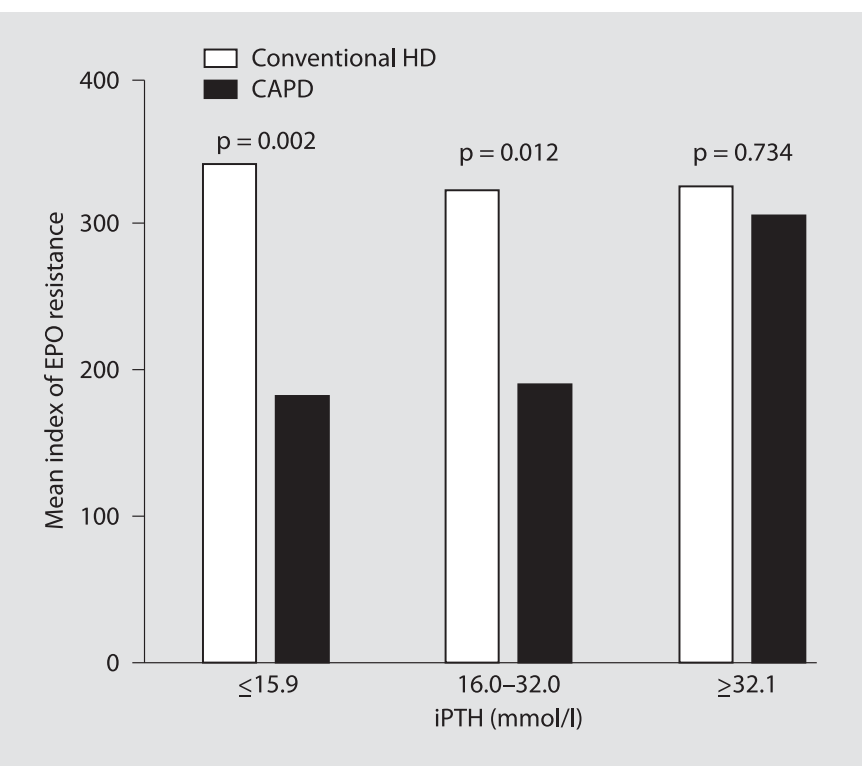

Fig. 1. Relation between rHuEPO resistance index and iPTH levels in HD and CAPD.

\section{Discussion}

Conflicting data have been reported regarding the role of parathyroid hormone in conditioning the response to rHuEPO in dialysis patients $[4,6,7]$. Few studies [10] have compared the responsiveness of erythropoietin
Table 3. Hb concentration at iPTH levels $<32$ and $>32 \mathrm{pmol} / \mathrm{l}$ for all the patients

\begin{tabular}{llll}
\hline \multicolumn{3}{c}{ iPTH, pmol/l } & \multirow{2}{*}{ p value $^{\mathrm{a}}$} \\
\cline { 2 - 3 } & $<32$ & $>32$ & \\
\hline $\mathrm{Hb}$ & & \\
$<11 \mathrm{~g} / \mathrm{dl}$ & $28(45.2 \%)$ & $36(64.3 \%)$ & 0.0433 \\
$>11 \mathrm{~g} / \mathrm{dl}$ & $34(54.8 \%)$ & $20(35.7 \%)$ & \\
$\mathrm{Hct}$ & & & \\
$<33 \%$ & $24(38.7 \%)$ & $33(56 \%)$ & \\
$>33 \%$ & $38(61.3)$ & $23(40 \%)$ & \\
\hline \multicolumn{2}{l}{$\begin{array}{l}\text { iPTH = Intact parathyroid hormone. } \\
\text { a Fisher's exact test. }\end{array}$} \\
\hline
\end{tabular}

therapy in patients with hyperparathyroidism and parathyroid hormone below the recommended level. Severe hyperparathyroidism is one of the factors involved in erythropoietin response [6]. Theoretically, medical and/ or surgical suppression of iPTH over secretion should have a similar effect on anemia detected in dialysis patients. Some authors reported a better response in patients with relative hypoparathyroidism [10]. Yet, others found no relationship between hyperparathyroidism and poor response to erythropoietin $[11,12]$. A higher requirement for $\mathrm{rHuEPO}$ in patients with elevated $\mathrm{iPTH}$ 
has been reported in HD patients. In peritoneal dialysis patients, the rHuEPO requirement is reduced, and there is less frequent administration of rHuEPO than in $\mathrm{HD}$ patients [13]. Our study has consistently shown that $\mathrm{Hb}$ was significantly better in patients with iPTH levels $<32 \mathrm{pmol} / \mathrm{l}$. Moreover the requirement for $\mathrm{rHuEPO}$ was less in CAPD than HD patients.

Considerable improvement of anemia has been noted in patients commenced on or switched to CAPD $[14,15]$. Generally, anemia in CAPD patients seems to be less severe than in $\mathrm{HD}$ patients, and a greater proportion of patients on CAPD achieve normal Hct than do patients on $\mathrm{HD}$. The underlying mechanisms may include such various factors as reduced blood (and iron) loss and improved EPO production. Better clearance of middle molecule substance in CAPD [16] than with standard HD could in part explain the reduced requirement of $\mathrm{rHuEPO}$ in this dialysis modality. Inhibitors of aminolevulinate dehydrase, an enzyme involved in $\mathrm{Hb}$ metabolism [17], and albumin-bound furancarboxylic acid, an inhibitor of erythropoiesis [18], are possibly removed more efficiently by peritoneal dialysis.

An important finding of our study was the strong association between indices of refractory anemia in the form of $\mathrm{rHuEPO}$ hyporesponsiveness and high levels ( $>32 \mathrm{pmol} / \mathrm{l}$ ) of parathyroid hormone. In this study, the overall ERI was significantly lower in CAPD than in HD when parathyroid hormone was $<32 \mathrm{pmol} / \mathrm{l}$. ERI, however, was not significantly different in HD compared to CAPD when iPTH was $>32 \mathrm{pmol} / \mathrm{l}$.

Better responsiveness was reported in patients on HD with relative hypoparathyroidism [10, 19]. A recent study has shown that higher serum calcium and phosphate levels are independently associated with better anemia control [20]. Inhibition of erythropoietic progenitors and changes in tissue sensitivity to erythropoietin and parathyroid hormone has been proposed to have a direct negative impact on the responsiveness to erythropoietin [21]. Additionally plasma level of erythropoietin dramatically increases 1-2 weeks after surgical parathyroidectomy [22].

\section{Conclusion}

CAPD patients showed a reduced $\mathrm{rHuEPO}$ requirement than HD patients. Treatment of anemia with rHuEPO is more easily achieved in CAPD than HD patients. ERI is lower in CAPD than in HD patients. Hyperparathyroidism is a predictor parameter of rHuEPO hyporesponsiveness in dialysis patients. We advocate a combined therapeutic approach, that is, treating both anemia and overproduction of parathyroid hormone.

\section{References}

1 Eschbach J, Adamson J: Recombinant human erythropoietin: implication for nephrology. Am J Kidney Dis 1988;11:203209.

-2 Macdougall IC: Monitoring of iron status and iron supplementation in patients treated with erythropoietin. Curr Open Nephrol Hypertens 1994;3:620-625.

3 Rosenlof K, Fyhrquist F, Tenhunen R: Erythropoietin, aluminum, and anemia in patients on haemodialysis. Lancet 1990;335:247249.

-4 Nakamoto H, Kanno Y, Okada H, Suzuki H: Erythropoietin resistance in patients on continuous ambulatory peritoneal dialysis. Adv Perit Dial 2004;20:111-116.

5 Muirhead N, Hodsman AB: Occult infection and resistance of anemia to $\mathrm{rHUEPO}$ therapy in renal failure. Nephrol Dial Transplant 1990;5:232-234.

$>6$ Rao DS, Shih MS, Mohini R: Effect of serum parathyroid hormone and bone marrow fibrosis on the response to erythropoietin in anemia. N Engl J Med 1993;328:171-175.
7 Drueke TB: Modulating factors in hematopoietic response to erythropoietin. Am J Kidney Dis 1991;18:87-92.

8 National Kidney Foundation, Kidney-Dialysis Outcomes Quality Initiative: K/DOQI Clinical practice guidelines: anemia of chronic kidney disease. Am J Kidney Dis 2001;37(suppl 1):S182-S238.

9 National Kidney Foundation, Kidney-Dialysis Outcomes Quality Initiative: K/DOQI Clinical practice guidelines for bone metabolism and disease in chronic kidney disease. Am J Kidney Dis 2003;37(suppl 3):S182S238.

10 Shih-Ping Hsu, Yu-Sen Peng, Mei-Fen Pai, Kuan-Yu Hung, Tun-jun Tsai: Infuence of relative hypoparathyroidism on the responsiveness to recombinant human erythropoietin in hemodialysis patients. Blood Purif 2003;21:220-224.

11 Komatsuda A, Hirokawa M, Haseyama T, et al: Human parathyroid hormone does not influence human erythropoiesis in vitro. Nephrol Dial Transplant 1998;13:20882091.
12 Gunnell J, Yeun JY, Depner TA, Kaysen GA: Acute phase response predicts erythropoietin resistance in haemodialysis and peritoneal dialysis patients. Am J Kidney Dis 1999; 33:63-72.

13 Coronel F, Herrero JA, Montenegro J, Fernandez C, Gandara A, Conesa J, Rivera MT, Torrente J, Portoles J, Gomez-Martino JR: Erythropoietin requirements: a comparative multicenter study between peritoneal dialysis and hemodialysis. J Nephrol 2003;16: 697-702.

14 Zappacosta AR, Caro J, Erslev AJ: Normalization of hematocrit in patients with endstage renal disease on continuous ambulatory peritoneal dialysis. Am J Med 1982;72: 53-57.

15 DePaepe MBJ, Schelstraete KHG, Ringoir SMG, Lameire NH: Influence of continuous ambulatory peritoneal dialysis on the anemia of end-stage renal disease. Kidney Int 1983;23:744-748. 
-16 Guolo M, Machalinski C, Biscoglio M, Stella AM, Franco C, Pataro L, de Salamanca RE, Batle A: Inhibition of erythrocyte aminolevulinate dehydratase by a $56.2-\mathrm{kD}$ peptide from uremic plasma. Exp Nephrol 1999; 7:236-241.

17 Fontanellas A, Coronel F, Santos JL, Herrero JA, Moran MJ, Guerra P, Tornero F, de Salamanca RE: Heme biosynthesis in uremic patients on CAPD or hemodialysis. Kidney Int 1994;45:220-223.
18 Niwa T, Yazawa T, Kodoma T, Uehara Y, Maeda K, Yamada K: Efficient removal of albumin-bound furancarboxylic acid; an inhibitor of erythropoiesis, by continuous ambulatory peritoneal dialysis. Nephron 1990; 56:241-245.

19 Kcomt J, Sotelo C, Raja R: Influence of adynamic bone disease on responsiveness to recombinant erythropoietin in peritoneal dialysis patients. Adv Perit Dial 2000;16: 294-296.

$\checkmark 20$ Kimata N, Akiba T, Pisoni RL, Albert JM, Satayathum S, Cruz JM, Akizawa T, Andreucci VE, Young EW, Port FK: Mineral metabolism and haemoglobin concentration among haemodialysis patients in the Dialysis Outcomes and Practice Patterns Study (DOPPS). Nephrol Dial Transplant 2005;20: 927-935.
1 Meytes D, Bogin E, Ma A, Dukes P, Massry SG: Effects of parathyroid hormone on erythropoiesis. J Clin Invest 1981;67:12631269.

22 Urena P, Eckardt, KU, Sarfati, E, Zingraff J, Zins B, Roullet JB, Roland E, Drueke T, Kurtz A: Serum erythropoietin and erythropoiesis in primary and secondary hyperparathyroidism: effect of parathyroidectomy. Nephron 1991;59:384-393. 